\title{
Sexual offenders register. A tool of additional repression or an element of rational defense for the local community?
}

\author{
ADAM KWIECIŃSKI \\ ORCID: 0000-0002-2652-2689 \\ Department of Executive Penal Law \\ University of Wrocław
}

The creation of an effective treatment system for sexual offenders has been one of the greatest challenges for almost every nation for many years. Ever since the 1980s it was widely known that the use of standard procedures toward sexual offenders bears no expected result. A search for methods which would prove adequate was undertaken as a result, and it quickly became apparent that the task is extremely difficult, especially for individuals with sexual preference aberrations. Until today, in spite of abundant financing and plenty of staff devoted to it, there is no acceptable way to prevent felons returning to this area. An opportunity to make political gain by irrational treatment of this kind of perpetrator is an additional complication - we can refer to such a situation as penal populism.

In the above mentioned circumstances the creation of a unified method would prove difficult. However, there are some similarities in the penal policy of various countries and the main difference can be summarized 
by two methods of approach: supervisory and therapeutic. ${ }^{1}$ The former assumes protection of the local community through intensive supervision over perpetrators who have been released from isolation facilities, either after serving a sentence or after staying in an inpatient treatment facility. The elements of this model are control-assistance actions taken toward the perpetrator by a probation officer, psychologist or social worker, or the mechanism of reconsidering judgments. ${ }^{2}$ For some time now, legal systems based on the idea of supervision have been additionally strengthened by the possibility of checking people applying for jobs in care and educational institutions and by building databases on persons convicted of sexual offenses mentioned in the title. Such a model was initially the domain of countries in the common law circle (USA, Great Britain, Canada, New Zealand, Australia). ${ }^{3}$ In recent years, however, more and more countries that have so far implemented the model of clinical work in dealing with sex offenders decided to strengthen it with control and supervisory elements, such as the register from the title, thus it is more and more often believed that countries such as France or even Poland in these systematics should be moved to the group of countries implementing the supervisory model. Despite this, it seems more correct to say that more and more countries are implementing actions toward this type of perpetrator in the hybrid model. In turn, the central point of the model of clinical work that dominates in Europe in the approach to sex offenders is the therapy that

1 A. Sakowicz, "The Register of Sex Offenders as a Means of Control. Comments on the solutions of selected foreign countries and the convention on the protection of human rights and Fundamental Freedoms", Zeszyty Prawnicze (Legal Notes) of the bureau of parliamentary analysis of the parliamentary office 2012, No. 4, p. 12. Also: A. Morawska, "Strategies of dealing with sexual offenders against children via the example of selected countries", Dziecko Krzywdzone (Hurt Child) 2004, No. 2, p. 7 and the following.

2 The mechanism of re-examination of sentences makes it possible to extend the sentence of imprisonment or to apply post-penal psychiatric internment for an indefinite period of time, cf. K. Lewandowska,"Penalize or treat? Strategies for dealing with perpetrators of sexual offenses against children via the example of selected countries", Dziecko Krzywdzone (Hurt Child) 2007, No. 3, p. 2 and the following.

3 More on this: G. Maron, "The sex offender registry in the United States legal order", Prokuratura i Prawo (Prosecution and Law) 2019, No. 4, pp. 20-53; B. Hołyst, "Forensic and criminologic evaluation of public sex crime databases", [in:] Przestepczość, dowody, prawo. (Crime, Evidence, Law) Jubilee book of Prof. B. Młodziejowski, eds. J. Moszczyński et al., Olsztyn 2016, pp. 369-383; K. Lewandowska, op. cit., pp. 1-13. 
takes place both during their sentence or psychiatric internment, as well as after ceasing to use these measures and punishments (Germany, the Netherlands, Italy, Denmark).

The Polish experience with this type of special control mechanism in dealing with sexual offenders is relatively short. Instruments of this nature were introduced only by the Act of May 13, 2016 on Counteracting the Threats of Sexual Crime. ${ }^{4}$ Although the authors of this act emphasized its necessity and effectiveness in the fight against this type of crime ${ }^{5}$, the individual solutions contained in the act raised numerous doubts from the very beginning, not only among lawyers, but also among therapists. Due to the limited volume of this publication, the main points of criticism against the new institutions will be presented in the summary of the work.

In line with the authors' intention, The Act sets out specific protection measures to counteract the threat of sexual crime (Art. 1). It is not difficult to discover from its content that the object of special concern of project promoters is protection against this type of danger to minors.

In art. 2 of The Act on Counteracting the Threats of Sexual Crime, a definition of this crime was included (which at the same time determined the area of regulation of this Act). It was decided that such events would include offenses against sexual freedom listed in Chapter XXV of the Criminal Code with certain exemptions (Art. 2). ${ }^{6}$ According to Art. 6 paragraph 1 of The Act beyond the legally convicted for committing crimes falling within this definition (Art. 2), certain control mechanisms referred to in The Act (i.e. Register with limited access and the obligations of employers and organizers of activities involving minors) are

4 Act of May 13, 2016 on counteracting the threats of sexual crime, Law Journal of 2016, item 862. It will be referred to as The Act later in the text.

5 Justification of the draft of The Act on counteracting threats of sexual crime, http://orka.sejm.gov.pl/Druki8ka.nsf/0/055744120464461FC1257F3A0050EAFB/\%24File/189.pdf (access: 20.07.2020).

6 These exclusions apply to the offenses specified in: Art. 201 PC (unless they have been committed to the detriment of a minor), Art. $202 \S 1$ PC, Art. $202 \S 3$ PC (consisting in the presentation of pornographic content related to violence or the use of an animal), Art. $202 \S 4$ a PC, Art. $202 \S 4$ b (consisting in the storage or possession of pornographic content presenting a created or processed image of a minor participating in a sexual activity), Art. $202 \S 4 \mathrm{c}$ PC, Art. $204 \S 1$ i 2 PC (unless they have been committed to the detriment of a minor). 
applicable to the individuals, against whom the criminal proceedings in cases related to these crimes have been legally and conditionally discontinued or protective measures have been validly adjudicated. Moreover, to some extent, they can also be used against minors. ${ }^{7}$ In fact, the only determinant of the application of these "special protection measures" is the commission of any of the crimes listed in Art. 2 of The Act.

Article 3 precisely lists the protective measures for the realization of The Act: the register of sexual offenders, the obligations of employers and other organizers in the field of education, treatment and care of minors, as well as pointing out areas of elevated threat of sexual crime (creating a Safety Map).

The register should be composed of three separate databases listed as:

a) A register with limited access

b) A public register

c) A register of persons against whom the state commission for the explanation of cases of activities directed against sexual freedom and decency toward a minor under the age of 15 , issued a decision on entry.

The register is kept by the Minister of Justice, and the related tasks are to be carried out by the Information Office of the National Criminal Register (the tasks are specified in Art. 5 of The Act).

The register with limited access collects data on all categories of persons referred to in Art. 6 sec. 1 items 1-4 of The Act. Information about minors is excluded from the public register (Art. 6 paragraph 1 point 4), and for the remaining categories of persons (listed in Art. 6 paragraph 1 point 1-3), the inclusion of data is conditioned by whether the legal qualification adopted in Art. $197 \S 3$ point 2 or $\S 4$ of the Penal Code, or whether these persons committed an offense specified in Art. 2 of The Act (definition of sexual crime), having previously been sentenced to imprisonment for such an offense, if any of them were committed to the detriment of a minor. The third database collects data on persons against whom the state commission for the investigation of actions against sexual freedom and decency against a minor under the age of 15 has issued a decision on entry.

7 The condition for their application to minors is a valid adjudication of educational, correctional or therapeutic measures or the imposition of a penalty in cases involving criminal offenses falling within the definition of "sexual crime", as defined in Art. 2 of The Act (excluding Art. $200 \S 1$ PC). 
In addition to the data on the perpetrator, collected from the National Criminal Register (Art. 7 paragraph 1), the register with limited access will include information on his PESEL number, face image (taken from the Register of Personal Identity Cards), and registered addresses for permanent or temporary residence and the actual address of the stay, obtained from the Police (Art. 7 paragraph 3). The information contained in the public register is modified by removing data that could lead to the actual identification of the place of residence of the person entered in the register (hence there is no place of residence, address of residence, actual address of residence, PESEL (personal ID) number and data about parents). In practice, this will only hinder the identification somewhat, in view of the fact that the database contains the surname and first name of this person paired with their image and the place where they are staying (Art. 7 paragraph 4). In the database where the data of persons entered by the decision of the state commission for the investigation of cases of actions directed against sexual freedom and decency against a minor under the age of 15 , there is information identifying the perpetrator, including a description of the act, the date of the decision on entry and possible data on the court's decision referred to by the person concerned by the alert (Art. 7 paragraph 4a).

Entering the data of persons referred to in art. 6 of The Act, occurs ex officio, as a consequence of legally valid decisions in their cases. However, the court may decide otherwise, taking into account the interests of the aggrieved party or the person who was to be entered in the register (Art. 9 paragraph 1-4 of The Act). This exclusion, however, must be justified either by the protection of private life or other important private interests of the victim or his relatives, and especially the interests of the minor victim. The second reason allowed by the Act to withdraw from this is the disproportionately severe consequences which for a person meeting the statutory conditions for entry in the register would be caused by entering their data there. Even stricter conditions for deviation in the matter have been formulated for persons who meet the formal criteria for inclusion in the public register (only an exceptional case, justified solely by the minor aggrieved party).

The inclusion of data in the register is related to the obligation imposed on the person entered into it to report his actual address of stay to the Po- 
lice (Art. 11). This obligation, which is not part of the conviction, is linked to the need to monitor the movements of sex offenders. The fulfillment of this obligation has been secured by defining a new offense directed against persons who fail to comply with these reports and are subject to arrest, restriction of liberty or a fine of not less than PLN 1,000 (Art. 23 paragraph 1). Both the data about the person included in the register and the obligation referred to above will be deleted or will expire when the conviction is obliterated or in other cases specified in Art. 18.

The group of entities that may use the information contained in the database with restricted access is specified in Art. 12 of The Act. Apart from law enforcement authorities, the judiciary and the government administration, the list includes employers and other organizers of activities that concern minors (in connection with the admission of a given person to work with minors), the state commission for investigating cases of activities directed against sexual freedom and decency toward a minor under the age of 15 and any person who wants to check whether their data is included in this database. The data from the public register and the Register of persons in relation to which the state committee for clarifying cases of actions against sexual freedom and decency against a minor under the age of 15 issued a decision on entry are available without restriction and published on the website of the Public Information Bulletin of the Ministry of Justice (Art. 16). The motives that drove the legislator when introducing new solutions emerge from a study of the Act of 13 May 2016. It is clear that the flagship element of the institutions aimed at counteracting the threats of sexual crime was the titular register. ${ }^{8}$ The drafters of the register say directly that it is the "most common means of control" and "providing data from the register about the perpetrators and the potential risks associated with being at large" is to help "stop the perpetrators from returning to crime and strengthen the social sense of security". 9 What may be worrying is the fact that the creators of new instruments against perpetrators of crimes against sexual freedom do not conceal that, apart from their warning and protective function toward

8 On registers of sex offenders operating in the world, also in the context of international standards: A. Sakowicz, op. cit., pp. 11-27.

9 Project rationale..., http://orka.sejm.gov.pl/Druki8ka.nsf/0/055744120464461FC1257F3A0050EAFB/\%24File/189.pdf (access: 10.07.2020). 
society, they are to constitute a certain ailment for convicts, which is by no means an unintended effect of their introduction. The new measures were presented by the legislator from the very beginning as a remedy for the outdated (and ineffective) solutions previously functioning in Polish criminal law. Less optimistic opinions appeared already during the procedure of the Act. The spokesman for Children's Rights claimed that the proposed regulations are dangerous for the victims and their families, as they expose the victims to secondary victimization and the perpetrator's relatives to social ostracism. In addition, his reservations were raised by entering into the databases of minors toward whom educational, corrective or educational and therapeutic measures were legally issued. ${ }^{10}$ The opinion sent from the Supreme Court revealed the fact that, despite the fact that the authors of the project promoted the protective function, the protective instruments provided for in the new act are repressive in nature, containing a significant ailment for the persons covered by them, and disproportionate to the implementation of the objectives set for the new law. ${ }^{11}$ The opinions emphasized that instruments such as the registers of perpetrators of sexual offenses will certainly have a negative impact on the social re-adaptation of perpetrators and will be an obstacle in continuing their therapy in freedom. Moreover, the Public Prosecutor General saw in the introduction of the registers a direct threat to the life and health of people whose data would be placed there. ${ }^{12}$

In the opinion of the National Council of the Judiciary, a clear breach of the principle of non-retroactivity was the consent to enter in the registers the data of perpetrators against whom final judgments were issued before the Act entered into force. Negative reviews of this authority also concerned the imprecise group of entities authorized and obliged to ob-

10 Opinion of the spokesman for Children's Rights on the draft Act on counteracting threats of sexual crime, http://orka.sejm.gov.pl/Druki8ka.nsf/0/99DA56804312848 9C1257F53003C9F23/\%24File/189-003.pdf (access: 10.07.2020).

11 Opinion of the President of the Supreme Court on the draft Act on counteracting threats of sexual crime, http://orka.sejm.gov.pl/Druki8ka.nsf/0/286891B901624F6BC1257F540060B96F/\%24File/189-004.pdf (access: 10.07.2020).

12 Opinion of the Prosecutor General on the draft Act on counteracting threats of sexual crime, http://orka.sejm.gov.pl/Druki8ka.nsf/0/26ACD8C94F6DA52BC1257F4700371EBB/\%24File/189-001.pdf (access: 10.07.2020). 
tain information from the limited register. ${ }^{13}$ Serious objections to violations of the right to privacy and the right to personal data protection were reported by the Inspector General for Personal Data Protection. ${ }^{14}$ Doubts were also raised against an excessively wide catalog of crimes, the commission of which results in entering the perpetrator's data into the listed databases. Opinions submitted to the government draft of this act (form No. 189) indicated that the control model referred to by the creators of instruments such as registers is borrowed from countries with a different legal culture and experiences with this type of crime. Therefore incorporation of the registry into the national legal system is not easy. Moreover, it was noticed that we still do not have studies that are able to reliably estimate its effectiveness. ${ }^{15}$

Only some of the comments submitted in the course of works on the government bill were taken into account. The act still arouses criticism in terms of individual solutions. One of the most contested areas of its regulation are solutions concerning minors. It is indicated that they are treated more severely than not only juvenile but also adult perpetrators of similar acts. ${ }^{16}$ The need to respect the constitutional rights and freedoms of minors, including the right to the protection of personal data and the best interests of the child, is justified. It also seems necessary to properly balance the best interests of the protected (juvenile and victim) in the

13 Opinion of the National Council of the Judiciary on the draft Act on counteracting sexual crime, http://orka.sejm.gov.pl/Druki8ka.nsf/0/D936D58F64C12280C1257F640038E22C/\%24File/189-005.pdf (access: 10.07.2020).

14 Opinion of General Inspector of Private Data Protection on the draft Act on counteracting threats of sexual crime, http://orka.sejm.gov.pl/Druki8ka.nsf/0/D5CB3E2799E4F5A9C1257F50004B5FC0/\%24File/189-002.pdf (access: 10.07.2020).

15 A. Sakowicz, "Legal opinion on the draft Act on counteracting the threats of sexual crime and amending certain other acts", Legal Notes Office of Parliamentary Analysis 2015, No. 2, page. 158 and the following. Opinion of the Helsinki Foundation for Human Rights: http://www.hfhr.pl/wp-content/uploads/2016/02/Opinia-HFPC-dorz\%C4\%85dowego-projektu-ustawy-o-przeciwdzia\%C5\%82aniu-zagro\%C5\%BCeniom -przest $\%$ C4\%99pczo\%C5\%9Bci\%C4\%85-na-tle-seksualnym.pdf (access: 20.02.2020).

16 A. Rękas, "Act on counteracting sexual threats — a few remarks", [in:] Z problematyki wiktymologii (From the Subject of Victimology). A book dedicated to Professor Ewa Bieńkowska, eds. W. Klaus et al., Warszawa 2017, p. 312 and the following. 
name of the principle of proportionality. ${ }^{17}$ After The Act entered into force, many solutions were questioned as inconsistent with constitutional standards and international regulations. In this context, beside other aspects the need for a public register was questioned, as it was accused of being ineffective, oppressive and obstructing social rehabilitation. The lack of real protection of the interests of the perpetrators and victims' families was emphasized. Both the wide range of entities entered into the databases and the related excessive hardship of the new control system were questioned. Reservations are raised in particular by the public register (Art. 6 paragraph 2 of The Act) and the lack of a decision as to the nature of the measure under review, the manner of its implementation and the material scope. Nevertheless, a limited register is also accused of a too wide access to data (in the field of scientific research). ${ }^{18}$

There were justifiable doubts arising from entering in the databases, inter alia, perpetrators of crimes under Art. $200 \S 1$ PC in a situation where the contact was voluntary and the perpetrator is a person not much older than the victim. Similar allegations concerned, for example, the perpetrator of the crime stipulated in Art. $199 \S 3$ of the PC or Art. $202 \S 4$ of the PC. In the context of violation of the principle of the presumption of innocence, the doctrine also raises doubts in the register of persons against whom the criminal proceedings have been legally discontinued or precautionary measures have been applied. ${ }^{19}$

One of the most serious allegations against the new registers concerns the fact that when assigning perpetrators to them, the subjective criteria, personal characteristics and conditions or the degree of guilt of the perpetrator were completely ignored. ${ }^{20}$ This does not allow for adjusting

17 A. Wolska-Bagińska, "Ochrona praw i wolności nieletniego a rejestr sprawców przestępstw na tle seksualnym" ("Protection of the rights and freedoms of minors and the register of sexual offenders"), Palestra 2018, No. 9, pp. 62-69.

18 E. Michalkiewicz, "Register of perpetrators of sexual crimes in terms of protection of human and civil rights", Prawo Mediów Elektronicznych (Law of Electronic Media) 2016, No. 2, p. 66. Also: J. Mierzwińska-Lorencka, "Register of sexual offenders. Comments on the background of the Act of May 13, 2016 on Counteracting the Threats of Sexual Crime", Studia Prawnicze (Legal Study) 2016, No. 4, pp. 152-160.

19 J. Mierzwińska-Lorencka, op. cit., pp. 152-155.

20 A. Sakowicz, "Legal opinion on the draft Act on counteracting the threats of sexual crime and amending certain other acts". 
the manner and scale of the reaction to the actual level of threat to the perpetrator. Thus, statutory automatism creates the risk of excessive repressiveness directed against persons who do not require the use of such instruments. No attempt was made to compensate for this risk at the stage of executive proceedings, for example making the effects of prison therapy or the use of protective measures dependent on entry in the registers.

The Polish model of dealing with perpetrators of sexual crimes from its inception in its basic outline was similar to the models based on therapeutic work. However, this is not a uniform model, and in recent years it has often been enriched with some control elements. It is true that these elements, despite the fact that they usually received negative reviews from practitioners and theorists, did not manage to destroy the basic assumptions of the therapeutic model, but weakened the strength of its impact. It will be similar in the case of The Act and the titular register. While some of the opinion on The Act accepts (provided it would be changed in several important ways) the need to introduce, for example, a limited register, the existence of a public register is considered a significant obstacle in the treatment of sex offenders. Keeping such databases makes sense only when associated with therapeutic interactions with the perpetrator. ${ }^{21}$ The solutions need to be unified and systemic and the supervisory elements can supplement the therapy, not vice versa. The maintenance of the introduced databases must be conditional on the elimination of those regulations which were, also in this publication, questioned as excessively repressive, unnecessary to achieve the objectives of the Act and violating the fundamental rights not only of the perpetrators, but also their families, victims and their relatives.

\section{Bibliography}

Hołyst B., "Forensic and criminologic evaluation of public sex crime databases", [in:] Przestępczość, dowody, prawo. (Crime, Evidence, Law) Jubilee book of Prof. B. Mtodziejowski, eds. J. Moszczyński et al., Olsztyn 2016.

21 Opinion of the Helsinki Foundation for Human Rights; also a resolution of the General Board of the Polish Sexological Society, http://pts-seksuologia.pl/sites/strona/50/ uchwala-zarzadu-glownego-polskiego-towarzystwa-seksuologicznego-z-dnia-22012016r (access: 27.07.2020). 
Lewandowska K., "Penalize or treat? Strategies for dealing with perpetrators of sexual offenses against children on the example of selected countries", Dziecko Krzywdzone (Hurt Child) 2007, No. 3.

Maroń G., "The sex offender registry in the United States legal order", Prokuratura i Prawo (Prosecution and Law) 2019, No. 4.

Michalkiewicz E., "Register of perpetrators of sexual crimes in terms of protection of human and civil rights", Prawo Mediów Elektronicznych (Law of Electronic Media) 2016, No. 2.

Mierzwińska-Lorencka J., "Register of sexual offenders. Comments on the background of the Act of May 13, 2016 on Counteracting the Threats of Sexual Crime", Studia Prawnicze (Legal Study) 2016, No. 4.

Morawska A., "Strategies of dealing with sexual offenders against children on the example of selected countries", Dziecko Krzywdzone (Hurt Child) 2004, No. 2.

Rękas A., "Act on counteracting sexual threats - a few remarks", [in:] Z problematyki wiktymologii (From the subject of victimology). A book dedicated to Professor Ewa Bieńkowska, eds. W. Klaus et al., Warszawa 2017.

Sakowicz A., "Legal opinion on the draft act on counteracting the threats of sexual crime and amending certain other acts", Legal Notes Office of Parliamentary Analysis 2015, No. 2.

Sakowicz A., "The Register of Sex Offenders as a Means of Control. Comments on the solutions of selected foreign countries and the convention on the protection of human rights and Fundamental Freedoms", Zeszyty Prawnicze (Legal Notes) of the bureau of parliamentary analysis of the parliamentary office 2012, No. 4.

Wolska-Bagińska A., "Ochrona praw i wolności nieletniego a rejestr sprawców przestępstw na tle seksualnym" (Protection of the rights and freedoms of minors and the register of sexual offenders), Palestra 2018, No. 9.

\section{Summary}

The publication is an analysis of the provisions of the Act of May 13, 2016 on counteracting the threats of sexual crime, in the extent of introducing a protective measure in the form of a register of sexual offenders. It not only introduces the legal regulation of this institution, but also attempts to present all controversies and doubts related to the introduction of title databases into the Polish legal system and their functioning in the following years. The considerations focus, but are not limited to, on securing the rights of persons whose data may be entered into registers, but also on the interests of victims and their families. An equally important element of the work is an attempt to answer the question whether the control model promoted by the legislator in dealing with this type of perpetrator is in opposition to therapeutic goals.

Keywords: sexual offense, public register, register with restricted access, perpetrator, therapy. 